\title{
Water quality as an indicator of local residents' attitudes towards tourism development: A case study of settlements along Veliki Bački Kanal, Vojvodina, Serbia
}

\author{
M. Pantelić(1), B. Đurđev(1), U. Stankov ${ }^{(1) \star}$, V. Dragićević(1), D. Dolinaj(1) \\ Received September 16, 2011 \\ Revised February 9, 2012 \\ Accepted February 14, 2012
}

\section{ABSTRACT}

Key-words: water quality, tourism, Veliki Bački Kanal

\begin{abstract}
Veliki Bački Kanal (VBK) is a very important waterway in Serbia and part of the Danube-Tisza-Danube hydro-system. VBK runs through the central part of Bačka, connecting the rivers of Danube and Tisza, and as such possesses high unused tourism potential. In order to develop tourism in this region, local residents' attitudes are being investigated in relation to the use of VBK for recreational and tourism purposes. The data obtained are analyzed in the statistical program SPSS. The sample comprised 500 respondents in ten settlements. In order to use a particular water surface for recreation and tourism development, it is necessary to have water of adequate quality. Water quality of watercourses is determined on the basis of the water quality index (WQI), a qualification system for describing water quality of surface waters. The research results showed that along the entire course of VBK, there are sections which are clean and entirely suitable for tourism development and sections which are completely degraded. Local residents have positive attitudes towards tourism development of VBK, in particular towards rural and ecotourism development. The results obtained offer an opportunity to determine guidelines which can influence tourism development in these and similar areas.
\end{abstract}

\section{RÉSUMÉ}

La qualité de l'eau comme indicateur de l'attitude des riverains vis-à-vis du développement du tourisme : une étude de cas des populations le long du canal Veliki Backi, Serbi

\section{Mots-clés :} qualité de l'eau, tourisme, Veliki Baéki canal
Veliki Bački Kanal (VBK) est une voie navigable très importante en Serbie et une partie de l'hydrosystème Danube-Tisza-Danube. VBK traverse la partie centrale de la région Bačka reliant les fleuves Danube et Tisza, et en tant que tel possède un fort potentiel touristique encore inutilisé. Afin de développer le tourisme dans cette région, les attitudes des résidents locaux par rapport à l'utilisation de VBK à des fins récréatives et à des fins touristiques ont été étudiées. Les données obtenues sont analysées avec le logiciel statistique SPSS. L'échantillon a comporté 500 répondants de dix populations. Pour utiliser une surface d'eau notamment pour le développement des loisirs et du tourisme, il est nécessaire d'avoir de l'eau de qualité adéquate. La qualité de l'eau des cours d'eau est déterminée sur la base du système de qualification de la qualité des eaux de surface par la méthode de 
l'indice de qualité de l'eau (WQI). Les résultats des recherches ont montré que le long du parcours complet de VBK, il y a des sections qui sont propres et tout à fait convenables pour le développement du tourisme et des parties qui sont complètement dégradées. Les résidents locaux ont des attitudes positives à l'égard du développement du tourisme de VBK, en particulier vers le développement rural et l'éco-tourisme. Les résultats de recherche obtenus offrent la possibilité de déterminer des lignes directrices qui peuvent influencer le développement du tourisme dans ces régions ou d'autres régions similaires.

\section{INTRODUCTION}

In the past few years, an increasing number of tourism research studies have been based on the attitudes of the residents (Andriotis and Vaughan, 2003; McGehee and Andereck, 2004; Ryan and Cave, 2005; Ishikawa and Fukushibe, 2006; Zhang et al., 2006; Almeida-Santos and Buzinde, 2007; Lepp, 2007).

One of the indicators of the appropriateness of tourism is residents' attitudes towards tourism. The study reported here used qualitative methods to elicit residents' attitudes towards tourism, as well as the factors which influenced those attitudes (Lepp, 2007).

Research conducted in this region is extremely important because positive and negative local residents' attitudes can have a great influence on the development of the tourism industry (Teye et al., 2002; Vargas-Sánchez et al., 2011). A large number of studies have examined residents' attitudes and the factors that are likely to influence those attitudes. Most of those studies suggest that locals tend to have positive attitudes because they see tourism as an economic development tool (Gursoy et al., 2002).

Positive attitudes towards tourism could lead to pro-tourism behavior such as local participation in tourism development and the conservation of the resources which tourism depends on. The tourism development process can be slow, tedious and on rare occasions inflammatory. In a tourism context, a variety of studies have shown a connection between tourists' attitudes and their behavioral intentions (Hudson and Ritchie, 2001; Lee et al., 2004; Yu and Littrell, 2005).

Research into residents' attitudes towards tourism has been used to judge the appropriateness of tourism for a particular settlement. Positive attitudes are an indication that the social and cultural obligations of tourism development are being met. In this regard, several variables have been used to explain residents' attitudes towards tourism (Brohman, 1996; Brown, 1998; Lawson et al., 1998; Timothy, 1999; Horn and Simmons, 2002).

Economic benefits have a significant influence on residents' attitudes towards tourism (King et al., 1992; Haralambopoulos and Pizam, 1994; Lindberg and Johnson, 1997; Andereck and Vogt, 2000; Vargas-Sánchez et al., 2009). Economic benefits, most notably revenue, make tourism very attractive to developing countries (Weaver, 1998).

Incentives and tourism development offer opportunities to develop and improve the economic situation of an area. The settlements along rivers and canals have always had greater potential for the development of certain forms of tourism.

Local residents' attitudes towards tourism development in river regions have received limited attention in the literature (Gillies et al., 1989; Clements et al., 1993; Carlson, 2002). The aim of this paper is to investigate local residents' attitudes towards the use of VBK for recreational and tourism purposes. In order to use a particular aquatorium for recreation and tourism development, it is necessary for its water to be of appropriate quality. Water quality of watercourses can be determined on the basis of the water quality index (WQI), a qualification system for describing water quality of surface waters; in this case, the Serbian water quality index (SWQI) for the VBK. This paper starts from the hypothesis that the attitudes of local residents will be in correlation with the quality of the canal water along the sections of VBK 
which are inhabited by the local population. The paper consists of two parts. The first part comprises the quality analysis of canal water by the SWQI method, whereas the second part relates to the investigation of local residents' attitudes.

\section{> AN OVERVIEW OF THE CASE STUDY AREA}

VBK was built in the 18th century for the purposes of water supply, navigation and drainage (Milovanov, 1986). Over time, a network of drainage and irrigation canals was formed around it as well as settlements with numerous buildings and agricultural compounds. Today, the functions of the canal are: irrigation, sport, recreation and tourism, but also collecting all wastewater from the settlements, industry and agricultural compounds along its banks (Andrejev, 2002). Intensive pollution of VBK started in the 1960s and the need for water treatment and remediation has existed for a number of years. Watercourse pollution is a largescale global problem, so this issue is being dealt with by a great number of researchers, in order to protect watercourses, and preserve and use them. The research by Joy et al. (1990), Mhatre et al. (1980), Sayeda et al. (2010), and Wang et al. (2008) deals with the issues of industrial and agri-industrial influences on watercourse pollution. In the region of VBK, the biggest threat is from wastewaters from the sugar, alcoholic drinks and oil industries. Globally, this problem was dealt with by Arvanitoyannis (2008), Casani et al. (2005), Contreras et al. (2000), Guo et al. (2006), and Rajkumar et al. (2010), and the use of filters and wastewater treatment before discharging it directly into the watercourse is mentioned as a basic solution.

Due to its favorable geographic position, the presence of the water surface - the canal, structures of technical culture (locks, mills, weirs, etc.), unique landscape, and the connectivity of its road traffic system to other local motorways and all larger settlements in Vojvodina, VBK and the surrounding settlements have tourism potential.

VBK covers a small area but represents a potential tourism destination. Using this and similar areas for tourism purposes represents the only alternative for the survival and development of the settlement in its surroundings. There are numerous global examples which confirm this. In Western Europe and the United States of America, there are often examples of using rivers, canals, canal locks and mills for tourism purposes. It is not rare to find examples of using buildings near canal locks as restaurants or smaller accommodation facilities. The protection and restoration of mills is often found in practice in industrially developed countries. There are a lot of motives for such actions, but the most common ones are esthetic, archeological, scientific, historic and educational. The United States of America is among the leading countries in mill restoration. Hamer's Mill, in Spring Mill State Park in Indiana was the first restored mill open to the public in 1930 (Hazen, 2000). Organized visits to mills, canals and canal locks began in the USA in the 1940s. A good example of this is The Chesapeake and Ohio (C\&O) Canal which goes from Cumberland to Washington, DC (National Park Service, 2004). Donald Edward McHenry, a park ranger, organized education (interpretation) for visitors to mills along the Chesapeake and Ohio Canal (C\&O). He also organized boating along the canal, using over 70 canal locks. Today, the canal is visited mostly by recreational visitors, interested in hiking and cycling. They visit canal locks, old mill ruins and renovated houses of lock guards, as well as natural attractions in the canal surroundings. The River Thames in England is also famous for its numerous canal locks. In the area from the Cotswolds to London, there are 44 canal locks (Merrett, 2007). From the Middle Ages, the middle and upper river streams were used for the construction of mills for the production of flour, paper and for other purposes. This meant that dams were built to redirect the water into the mill. However, the dams represented obstacles for river traffic, so they started building canal locks.

VBK has hydro facilities representing a cultural and hydro-industrial heritage that is under state protection with immense tourist potential, similar to the above examples. The Bezdanska locks, the complex in Mali Stapar and the lock in Becej stand out as the most important facilities (Đekić and Šogorov, 2007). 


\section{MATERIALS AND METHODS}

\section{$>$ WATER QUALITY DATA}

The Serbian water quality index (SWQI). This system of describing water quality represents a method of quality assessment for a group of chosen parameters, and previous research and published papers show that the application of this method can result in a comprehensive presentation of the surface water quality in Serbia (Veljković, 2000a, 2001, 2003; Đurasković and Vujović, 2004; Veljković and Javičić, 2007; Đurašković and Tomić, 2009). Essentially, the method of the Serbian water quality index (SWQI) is that ten chosen parameters (oxygen saturation, BOD5, ammonium ion, $\mathrm{pH}$ value, total oxidized nitrogen, orthophosphates, suspended solids, temperature, electrical conductivity and $E$. coli bacteria) with their quality (qi) represent the characteristics of surface waters, yielding one index number. The proportion of each of the ten chosen parameters in the total water quality does not have the same relative significance, because each has a given weight (wi) and number of points according to its role in endangering the quality. The sum of products (qi $x$ wi) gives the index 100 as an ideal sum of weights of all the parameters (Development of a Water Quality Index, 1976; Oregon Water Quality Index Summary Report, 1996-2005). How many index points from 0 to 100 will be assigned to a particular water surface depends on the points of individual parameters.

In order to present the existing water quality of VBK, the database of the Republic Hydrometeorological Service of Serbia for the year 2009 was used (RHMS, 2009). The formula which is used to calculate the SWQI is as follows:

SWQI $=0.18$ oxygen saturation +0.15 BOD5 +0.12 ammonium $+0.09 \mathrm{pH}+0.08$ total oxidized nitrogen +0.08 orthophosphate +0.07 suspended solids +0.05 temperature +0.06 conductivity +0.12 E. coli /MPN.

The water quality index (WQI) represents criteria for the classification of surface waters based on the standard parameters for water categorization (House and Newsome, 1989; Smith, 1989; Melloul and Collin, 1998; Nives, 1999; Pesce and Wunderlin, 2000; Swamee and Tyagi, 2000; Cude, 2001; Nagel, 2001; Liou et al., 2003). The method of the water quality index (WQI) is used worldwide and basically provides a mechanism for cumulative presentation, numerical representation and definition of a particular water quality level (Hambright et al., 2000; Miller et al., 1986; Jonnalagadda and Mhere, 2001). A single parameter is not a sufficient and appropriate way of expressing water quality. Defining total water quality is not an easy task, especially when diverse criteria are applied for different purposes (Hambright et al., 2000). There are numerous definitions for water quality classification according to different parameters (Greve, 1990), and tens of such variations have been developed so far (Smith, 1989; Wang, 2001).

\section{> DATA ON LOCAL RESIDENTS' ATTITUDES}

The instrument used in the research is a multiple-choice questionnaire divided into three parts. The first part consists of items related to social and demographic characteristics of the respondents, the second part is related to the respondents' attitudes, and the third part is assessment. The instrument used in the third part is a scale by which the respondents assess the possibilities of using VBK for tourism development. In this research, as well as in similar research, the Lickert scale was used (Williams and Lawson, 2001; Gursoy et al., 2002; Ko and Stewart, 2002; Gursoy and Rutherford, 2004; Vargas-Sánchez et al., 2009) The answers are given by circling one of the numbers on a numerical scale ranging from 1 as the lowest score, to 5 as the highest score.

The obtained data are analyzed in the statistical program SPSS, which has been applied in similar research so far (Vuković et al., 2002). Statistical analyses which are the most common and have been applied in this research are: the application of the Pearson Chi-square test (Williams and Lawson, 2001), descriptive statistical analysis (Maguire and Klobučar, 2011), t-test analysis for independent samples (Sheldon and Abenoja, 2001; Teye et al., 2002; Kuvan 
and Akan, 2005; Mbaiwa and Stronza, 2011) and one-way analysis of variance, ANOVA (Smith and Krannich, 1998; Williams and Lawson, 2001; Paillisson et al., 2011; Pârvulescu et al., 2011; Vargas-Sánchez et al., 2011).

Descriptive statistical analysis was applied to calculating average scores by items and by respondent groups. The application of this method gave the arithmetic mean, mode, median and standard deviation. In order to determine the significance of the difference among individual groups, the post-hoc Scheffe test was used (Banha and Anastácio, 2011) as one of the most rigorous and most commonly applied tests (Pec, 1981). The sample fulfills basic conditions for the application of parametric tests, i.e. the data used in the analysis come from the interval scale and are normally distributed.

\section{> SAMPLING AREA}

The canal connecting the Danube and the Tisza, from Bezdan to Bečej, is part of a complex hydro-system and consists of several canals connected by weirs and canal locks (Likić, 2002). The length of VBK in central Bačka is $123 \mathrm{~km}$ (Milošev, 2002). Along the entire length of the course of VBK, the RHMS (Republic Hydrometeorological Service) performs measurements of particular physical and chemical parameters on five profiles, analyzed in this research. Profile I, near Sombor, profile II, near Mali Stapar, profile III, near Vrbas 1 (upstream of the weir), profile IV, near Vrbas 2 (downstream of the weir) and profile V, near Bačko Gradište (Figure 1). Along the canal, settlements were formed - Sombor, Mali Stapar, Sivac, Crvenka, Kula, Vrbas, Srbobran, Turija, Bačko Gradište and Bečej, and these settlements will be the subject of further investigation.

\section{> QUESTIONNAIRE STUDY}

Local residents from ten settlements - Sombor, Mali Stapar, Sivac, Crvenka, Kula, Vrbas, Srbobran, Turija, Bačko Gradište and Bečej - were used as the sampling frame for this study. The sample comprised nearly $1 \%$ of the population in these settlements. Local residents were approached and invited to participate in the data collection process on a voluntary basis. Data collection was conducted over 14 days in the central areas of the settlements where the circulation of local residents is the most evident. Our successful interceptions resulted in 500 useable surveys. This type of survey proved to be appropriate as local people agreed to answer the research questions and actively participate in this study. The local residents are aware of the bad economic situation in the settlements around VBK and positively respond to any type of research that could affect the improvement of economic development.

\section{RESULTS}

\section{$>$ WATER QUALITY INDEX (WQI)}

Based on the WQI categorization, the values are determined for the descriptive quality indicators $\mathrm{WQI}=0-38$ very poor, $\mathrm{WQI}=39-71$ poor, $\mathrm{WQI}=72-83$ good, $\mathrm{WQI}=84-89$ very good and WQI $=$ 90-100 excellent (Veljković, 2000b).

The WQI values on profile I, near Sombor (Table I) range from 70 (poor) in the summer period to up to 93 (excellent) in the fall period. Mali Stapar (Table I) is the profile where the highest WQI values were calculated. During summer, water quality is characterized as good (WQI = 83), during winter and in spring it is very good (WQI = 88; 85) and in fall, excellent (WQI = 90). Vrbas 1 (Table I) is also a profile characterized by high WQI values, especially in the fall and winter periods (WQI $=92 ; 90)$. During spring water quality falls under the category very good $(\mathrm{WQI}=86)$, and during summer under the category good $(\mathrm{WQI}=81)$. The study shows that the WQI on the profile Vrbas 2 (Table I) in all the observed periods is less than 38, i.e. it falls under the category very poor. An alarming situation and extremely poor values of WQI are recorded 


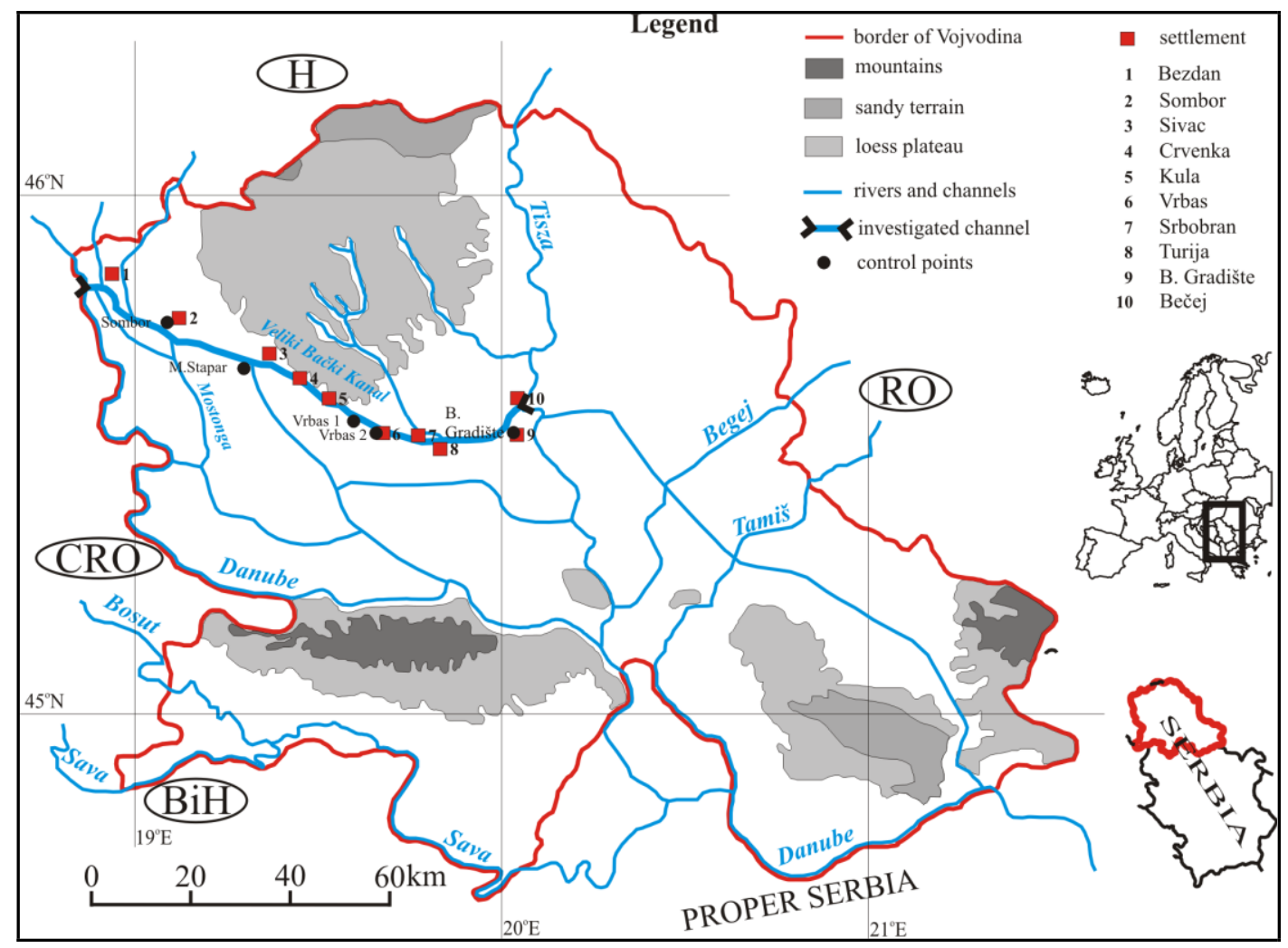

Figure 1

Map with the distribution of settlements and profiles.

\section{Table I}

Water quality index for the year 2009 for five profiles on VBK.

\begin{tabular}{|l|c|c|c|c|c|}
\hline Season & Sombor & Mali Stapar & Vrbas 1 & Vrbas 2 & Bačko Gradište \\
\hline Spring & 81 & 85 & 86 & 28 & 65 \\
\hline Summer & 70 & 83 & 81 & 25 & 67 \\
\hline Fall & 93 & 90 & 92 & 37 & 73 \\
\hline Winter & 85 & 88 & 90 & 32 & 65 \\
\hline
\end{tabular}

during the warmer period of the year. On the downstream section of VBK, on profile $V$ near Bačko Gradište (Table I), WQI values are rather low and during spring, summer and winter, they fall under the category poor (WQI $=65 ; 67 ; 65)$. During fall, these values are slightly higher and fall under the category good $(\mathrm{WQI}=73$ ). If $\mathrm{WQI}>80$, living conditions are acceptable for wildlife. Also, such water can be used for navigation, irrigation, recreation (swimming) and even for water supply with adequate water treatment (Yunus and Nakagoshi, 2004).

\section{> RESPONDENTS' PROFILES}

There were 500 respondents participating in the questionnaire, 268 males and 214 females. The proportional difference between male and female respondents can be explained by the fact that the total percentage of the male population in these settlements is higher than the number of females. Most of the respondents belong to the age group 25-50 (52.8\%). A smaller percentage of the respondents belongs to the age group up to 25 years of age $(26.6 \%)$ 
and over 50 years of age (20.6\%). A significant percentage of people in the age group 25-50 can be observed, due to the fact that these persons are dominant in the total age structure of the population in these settlements. The structure of the respondents by the level of educational attainment was chosen to reflect approximately the educational structure of the population in these settlements. Most of the respondents have a high school degree $(72 \%)$, followed by college and university graduates $(20 \%)$ and primary school (8\%). About fifty respondents in each settlement were interviewed, which is $10 \%$ out of the total number of respondents in each settlement.

\section{> LOCAL RESIDENTS'ATTITUDES}

When asked What is the main motive for tourists to visit Veliki Bački Kanal, most of the respondents, up to $27 \%$, replied that the canal was polluted and that there was no reason for tourist visits. $25.8 \%$ of the respondents consider fishing as a dominant motive for attracting tourists, whereas $22.2 \%$ think that it would be having a holiday in nature. About $13 \%$ of the respondents mentioned enjoying walks or riding a bicycle as a dominant motive, $7.8 \%$ swimming, and $4.2 \%$ of the local residents think it is boating.

\section{> RESULTS OF THE CHI-SQUARE TEST}

The application of the Chi-square test gave results (Table II) which show that the male population mentions fishing as the most dominant motive, whereas women strongly feel that the canal is extremely polluted and that there is no motive for tourist visits. Based on the Chisquare value $(p=0.000)$ we can conclude that there is a significant difference between the real and the expected data. Female respondents are more inclined to relaxation and enjoyment in nature, and therefore point out that pollution of VBK affects tourists negatively, giving them no motive to visit the canal. If the odors originating from the polluted canal water expand and create an unpleasant environment and health risks, there will be few of those who will come to visit cultural and historical sites of this area.

The results of the responses by age structure of the respondents (Table II) show that the biggest percentage of persons younger than 25 and older than 50 years of age think that tourist visits to VBK could be motivated by fishing, whereas persons in the age group 25 to 50 think that the canal is extremely polluted and it does not have any tourism potential. The value of the Chi-square $(p=0.006)$ confirms that the difference between the real and expected data is significant at $p<0.01$.

The data obtained through the analysis of the responses by the age structure of the respondents (Table II) show that persons with primary school education think that tourists could be attracted to VBK to enjoy swimming, and persons with secondary school education think it is fishing, whereas most of the persons with college or university degrees consider the canal to be extremely polluted and without tourism potential. The difference between the real and expected data is significant at the level of significance $p<0.01(p=0.002)$, which is confirmed by the value of the Chi-square test. The highest difference in the responses is between the respondents with primary school and respondents with secondary school education.

The analysis of the responses by settlement (Table II) shows that the residents of Bezdan, Sombor, Sivac and Turija mentioned a holiday in nature as a dominant motive for tourist visits to VBK, and the residents of Kula and Bačko Gradište chose fishing, whereas the residents of Crvenka, Vrbas, Srbobran and Bečej think the canal is extremely polluted and that there is no basis for the development of any type of tourism. Based on the value of the Chi-square $(p=$ 0.000 ), we can conclude that there is a significant difference at $p<0.01$. The differences in the responses are the biggest between the residents of Sivac and the residents of Vrbas. The results of the questionnaire are in correlation with the result of water quality analysis in these areas. Extremely poor quality of the canal water (WQI $=25-37)$ in the vicinity of Crvenka, Vrbas and Srbobran supports the attitudes of the local population in this area and there are no motives or conditions for the development of tourism. On the other hand, the water quality of 


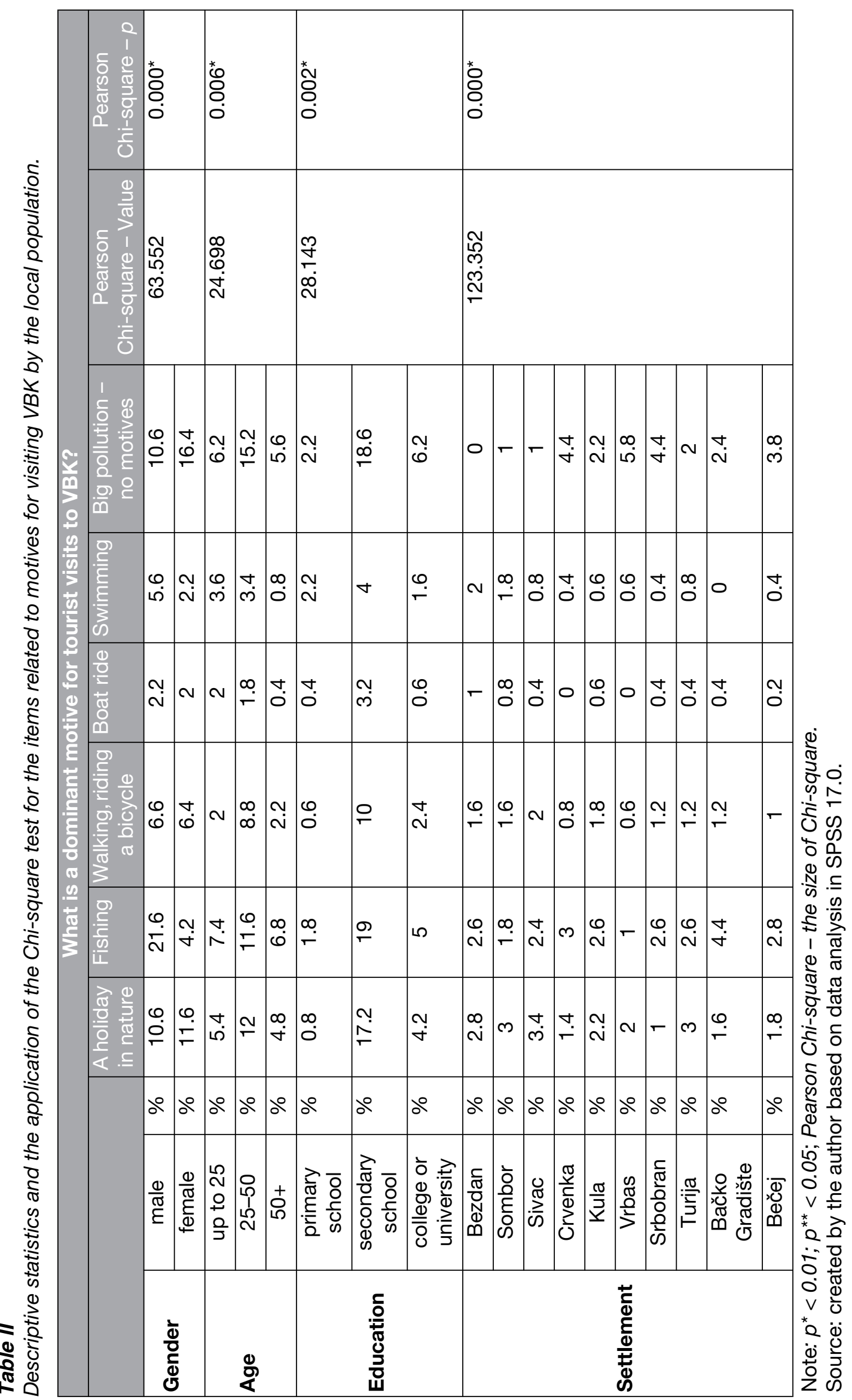


Table III

Descriptive statistics for the questions referring to the attitudes of the local population and the possibilities of using VBK for the development of tourism.

\begin{tabular}{|l|c|c|c|c|}
\hline Item & $M$ & $\sigma$ & Median & Mode \\
\hline $\begin{array}{l}\text { You think that the canal can be used for navigation } \\
\text { and the development of nautical tourism }\end{array}$ & 3.45 & 1.502 & 4 & 5 \\
\hline $\begin{array}{l}\text { You think that the canal can be used for fish } \\
\text { farming and the development of sport-fishing } \\
\text { tourism }\end{array}$ & 3.33 & 1.573 & 4 & 5 \\
\hline $\begin{array}{l}\text { You think that a part of the canal should be } \\
\text { protected for the preservation of bio-, geo- and } \\
\text { hydro-diversity and the development of ecotourism }\end{array}$ & 3.59 & 1.509 & 4 & 5 \\
\hline $\begin{array}{l}\text { You think that the canal can be used for the } \\
\text { development of rural tourism }\end{array}$ & 3.58 & 1.581 & 4 & 5 \\
\hline
\end{tabular}

Note: $M$ - arithmetical mean; $\sigma$ - standard deviation.

Source: created by the author based on data analysis in SPSS 17.0.

VBK in the surrounding area of other settlements is good (WQI > 72) so the possibilities for the development of tourism are justified.

\section{> RESULTS OF DESCRIPTIVE STATISTICS}

Within the single variant statistical analysis, data analysis was conducted through the procedures of frequency and descriptive statistics. The first procedure shows absolute frequency (the number of characteristic value repetition) and relative frequency (percentage proportion of the characteristic in the total sample size). Results obtained by the procedure of frequency are used for sample description. Table III shows the average score per question referring to the attitudes of the local population and possibilities for using this section of VBK for the development of tourism (M), standard deviation ( $\sigma)$, mode and median.

The values of the arithmetical mean for the items referring to the attitudes of the local population about the possibilities of using this section of VBK for the development of tourism (Table III) range from 3.33 (the lowest value, referring to the possibility of using VBK for fish farming and the development of sport and recreational tourism) to 3.59 (the highest value, referring to the possibility of using VBK for the development of ecotourism). Based on these results, we can conclude that the local population has an extremely positive attitude towards the possibility of using VBK for the development of different forms of tourism. This is confirmed by the mode (the most frequent score) which is 5 for all the items, as well as by the median (the central value of a set), which is 4 for all the items. Since all the values for items are approximately the same, it can be said that there is a symmetrical distribution of frequencies. Standard deviation, which shows the middle measure of the deviation of individual scores from the arithmetical mean, exceeds the value 1 for all the questions, and ranges in the interval from 1.502 to 1.581 . The results are in compliance with other similar studies, which connect positive attitudes of local residents towards tourism with a positive economic influence on the local community (Yoon et al., 2001). Descriptive analysis of mean values shows that the highest percentage of respondents think that, in the first place, there are conditions for intensive development of ecotourism on the canal, then rural tourism, and, finally, nautical and sport-fishing tourism. The development of sport-fishing tourism is directly linked to the water, therefore it is not surprising that this type of tourism is in the last place in local residents' opinions, mostly because of pollution and poor water quality in some sections. 
Table IV

Analysis of the t-test - the attitudes of the local population of different genders towards the possibilities of using VBK for the development of tourism.

\begin{tabular}{|c|c|c|c|c|c|}
\hline Item & Gender & $M$ & $\bar{\sigma}$ & $t$-test & $\bar{p}$ \\
\hline \multirow{2}{*}{$\begin{array}{l}\text { You think that the canal can be used for } \\
\text { navigation and the development of nautical } \\
\text { tourism }\end{array}$} & $M$ & 3.39 & 1.515 & \multirow[t]{2}{*}{-1.065} & \multirow[t]{2}{*}{0.287} \\
\hline & $F$ & 3.53 & 1.484 & & \\
\hline \multirow{2}{*}{$\begin{array}{l}\text { You think that the canal can be used for fish } \\
\text { farming and the development of sport- } \\
\text { fishing tourism }\end{array}$} & $M$ & 3.41 & 1.521 & \multirow[t]{2}{*}{1.344} & \multirow[t]{2}{*}{0.180} \\
\hline & $\mathrm{F}$ & 3.22 & \begin{tabular}{|l|}
1.637 \\
\end{tabular} & & \\
\hline \multirow{2}{*}{$\begin{array}{l}\text { You think that a part of the canal should be } \\
\text { protected for the preservation of bio-, geo- } \\
\text { and hydro-diversity and the development of } \\
\text { ecotourism }\end{array}$} & $M$ & 3.71 & 1.447 & \multirow[t]{2}{*}{1.999} & \multirow[t]{2}{*}{$0.046^{*}$} \\
\hline & $\mathrm{F}$ & 3.43 & 1.578 & & \\
\hline \multirow{2}{*}{$\begin{array}{l}\text { You think that the canal can be used for the } \\
\text { development of rural tourism }\end{array}$} & $M$ & 3.67 & 1.518 & \multirow[t]{2}{*}{1.411} & \multirow[t]{2}{*}{0.159} \\
\hline & $\mathrm{F}$ & 3.47 & 1.658 & & \\
\hline
\end{tabular}

Note: $p<0.01 ;{ }^{* *} p<0.05 ; t>2.58 ; M$-male; F-female.

Source: created by the author based on data analysis in SPSS 17.0.

\section{> RESULTS OF THE T-TEST}

The $t$-test for independent samples is used for comparing mean values of the results and for determining the statistical significance of their differences. The $t$-test of independent samples was applied with the purpose of comparing the arithmetical means of the two groups - male and female respondents.

The results of the $t$-test for the attitudes of the local population of different genders towards the possibility of using VBK for the development of different forms of tourism (Table IV) show that there is no statistically significant difference in the residents' responses at the level of significance $p<0.01$. The only small statistically significant difference $(p=0.046)$ in responses of the male and female populations can be observed in the case of the development of ecotourism, where male residents more strongly feel that this is the most promising form of tourism. This difference is statistically significant at the level of significance $p<0.05$. Male respondents in a greater degree consider that VBK has tourism potential, which correlates with previous responses related to the motives that attract tourists. Male respondents highlight several positive motifs (fishing, boating, swimming) while the female population in the first place emphasizes the problem of pollution in certain sections. Those justify lower scores when it comes to the possibility of ecotourism development.

\section{> RESULTS OF ONE-WAY ANALYSIS OF VARIANCE, ANOVA}

The application of one-way analysis of variance, ANOVA, was used to investigate if there is a statistically significant relationship between dependent variables (items related to the attitudes of the local population) and independent variables (social and demographic characteristics of the respondents). Independent variables included in this study are: age structure, educational structure, settlement and proximity of the residential building to VBK. Research results can show if there are differences in respondents' attitudes towards different forms of tourism (Gursoy et al., 2009)

The results obtained on the basis of age and educational structure of the respondents show that there is no statistically significant difference at the level of significance $p<0.01$, considering their attitudes towards the possibility of using VBK for the development of different forms of tourism. Categories of the younger population think, to a larger extent, that 
VBK has the greatest potential for the development of fishing tourism and ecotourism, whereas the older categories think that the canal provides more opportunities for the development of rural tourism. Ecotourism has both economic and educational components. According to the results, the young population has a positive attitude towards this form of tourism. This fact is a good starting point for organizing volunteers' camps for youth. Tourists are very interested in cultural heritage, but apart from the cultural values they are also attracted by authentic villages. Development of rural tourism is an essential precondition for solving economic problems in this region (Yoon et al., 2001). Elderly people should be included in rural tourism activities, as they emphasize VBK is suitable for rural tourism development.

Considering their educational structure, persons with higher levels of educational attainment think that the canal has greater potential for the development of ecotourism and rural tourism, whereas persons with lower levels of educational attainment are in favor of sport and recreational tourism. These results are in compliance with similar earlier studies (Janaim, 1997; Padtrapornnan, 1998; Kannasombat, 1999; Sangpikul and Batra, 2007). Persons with higher levels of education are aware that the development of ecotourism could greatly influence the reduction of environmental pollution. Respondents with lower levels of education are not so well versed in all the possibilities of sustainable use of VBK, and therefore give priority to its primary function, to navigation and fishing, that is, to the development of sports and recreational forms of tourism.

The responses and attitudes of the respondents from different settlements regarding the possibilities of the development of tourism on VBK are very different and statistically significant to a great extent.

Nautical tourism is an increasingly popular form of tourism. In contemporary tourism, navigation is one of the ways to escape everyday stress for a week, one day or for just a few hours. Regarding the possibility of navigation and the development of nautical tourism (Table V), we can observe that the residents of Sivac and Turija think that there is a possibility of using VBK for navigation, sport and recreation and gave this form of tourism very high scores (mean value higher than 4), whereas the residents of Vrbas consider this form of tourism almost impossible to develop (mean value 1.88). The variance analysis confirmed (Table V) the difference among the respondents from different settlements at the level of significance $p<0.01$ $(F=12.679, p=0.000)$. The difference can be observed between Vrbas and almost all other settlements, but it is the biggest between the residents of Turija and the residents of Vrbas. The results of the questionnaire research are in correlation with the analysis of water quality in these areas. The values of WQI $>80$, which are necessary for a particular watercourse to be adequate for the development of sport and recreation, were recorded on the profiles I, II, and III, i.e. in the vicinity of the settlements of Bezdan, Sombor and Sivac. In this section of the canal, the water is mainly of adequate quality during all periods of the year. A rather poorer quality of water was recorded in the summer period in the vicinity of Sombor. On the profile IV, near Vrbas 2, very low values of the WQI $(\mathrm{WQI}<37$ ) were calculated during the whole year and very poor water quality in the canal was recorded. The presence of a large amount of solid matter is connected to the erosion of soil and river canals, but also to the transport of nutrients (especially phosphorus), metals, industrial waste and chemicals used in agriculture (Dalmacija and Tumbas-Ivančev, 2004). Due to minimum flow, soil erosion and other unfavorable influences, this area formed a layer of sediment whose thickness in certain places exceeds $1 \mathrm{~m}$. The depth of the canal in this area is very shallow, only $20-30 \mathrm{~cm}$, which is why it is not possible to have any type of navigation, which was completely agreed upon by the local population. On profile V, near Bačko Gradište, the values of the WQI are much higher (WQI > 65) and it is impossible to navigate in this section of the canal and develop nautical tourism, which is also mostly agreed upon by the residents of Srbobran, Turija, Bačko Gradište and Bečej.

Sport and fishing, as some of the most frequent tourist activities on water, also represent one of the biggest opportunities for using VBK for tourism purposes. These activities are already popular among local residents. Their tourism development is also related to the problems of environmental protection on the canal and its vicinity (Presentation, Promotion and Activation 
Table $V$

Analysis of variance, ANOVA - attitudes of local residents of different settlements towards the possibilities of using VBK for tourism development.

\begin{tabular}{|c|c|c|c|c|c|}
\hline Item & Settlement & $M$ & $\sigma$ & $F$ & $p$ \\
\hline \multirow{10}{*}{$\begin{array}{l}\text { You think that the canal } \\
\text { can be used for } \\
\text { navigation and the } \\
\text { development of nautical } \\
\text { tourism }\end{array}$} & Bezdan & 3.8 & 1.34 & \multirow[t]{10}{*}{12.679} & \multirow[t]{10}{*}{$0.000^{*}$} \\
\hline & Sombor & 3.78 & 1.266 & & \\
\hline & Sivac & 4 & 1.498 & & \\
\hline & Crvenka & 3.16 & 1.53 & & \\
\hline & Kula & 3.34 & 1.493 & & \\
\hline & Vrbas & 1.88 & 1.35 & & \\
\hline & Srbobran & 3.8 & 1.325 & & \\
\hline & Turija & 4.36 & 1.083 & & \\
\hline & Bačko Gradište & 3 & 1.294 & & \\
\hline & Bečej & 3.38 & 1.413 & & \\
\hline \multirow{10}{*}{$\begin{array}{l}\text { You think that the canal } \\
\text { can be used for fish } \\
\text { farming and the } \\
\text { development of sport- } \\
\text { fishing tourism }\end{array}$} & Bezdan & 3.82 & 1.273 & \multirow[t]{10}{*}{10.642} & \multirow[t]{10}{*}{0.000} \\
\hline & Sombor & 3.84 & 1.299 & & \\
\hline & Sivac & 3.96 & 1.384 & & \\
\hline & Crvenka & 3.3 & 1.568 & & \\
\hline & Kula & 2.9 & 1.594 & & \\
\hline & Vrbas & 1.84 & 1.33 & & \\
\hline & Srbobran & 3.12 & 1.599 & & \\
\hline & Turija & 3.88 & 1.493 & & \\
\hline & Bačko Gradište & 2.88 & 1.52 & & \\
\hline & Bečej & 3.76 & 1.408 & & \\
\hline \multirow{10}{*}{$\begin{array}{l}\text { You think that a section } \\
\text { of the canal should be } \\
\text { protected for the } \\
\text { preservation of bio-, } \\
\text { geo- and hydro- } \\
\text { diversity and the } \\
\text { development of } \\
\text { ecotourism }\end{array}$} & Bezdan & 4.02 & 1.169 & \multirow[t]{10}{*}{9.455} & \multirow[t]{10}{*}{$0.000^{*}$} \\
\hline & Sombor & 3.72 & 1.539 & & \\
\hline & Sivac & 4.32 & 1.168 & & \\
\hline & Crvenka & 3.36 & 1.509 & & \\
\hline & Kula & 3.3 & 1.474 & & \\
\hline & Vrbas & 2.2 & 1.525 & & \\
\hline & Srbobran & 3.68 & 1.518 & & \\
\hline & Turija & 4.32 & 1.22 & & \\
\hline & Bačko Gradište & 3.46 & 1.593 & & \\
\hline & Bečej & 3.54 & 1.249 & & \\
\hline
\end{tabular}


Table $V$

Continued.

\begin{tabular}{|c|c|c|c|c|c|}
\hline Item & Settlement & $M$ & $\sigma$ & $F$ & $p$ \\
\hline \multirow{10}{*}{$\begin{array}{l}\text { You think that the canal } \\
\text { can be used for the } \\
\text { development of rural } \\
\text { tourism }\end{array}$} & Bezdan & 4.44 & 1.013 & \multirow[t]{10}{*}{14.721} & \multirow[t]{10}{*}{$0.000^{*}$} \\
\hline & Sombor & 4.18 & 1.137 & & \\
\hline & Sivac & 4.38 & 1.227 & & \\
\hline & Crvenka & 2.78 & 1.657 & & \\
\hline & Kula & 3.12 & 1.624 & & \\
\hline & Vrbas & 2.08 & 1.589 & & \\
\hline & Srbobran & 3.74 & 1.536 & & \\
\hline & Turija & 4.22 & 1.329 & & \\
\hline & Bačko Gradište & 3.46 & 1.432 & & \\
\hline & Bečej & 3.44 & 1.459 & & \\
\hline
\end{tabular}

Note: ${ }^{*} p<0.01 ; F \geq 3.32$.

Source: created by the author based on data analysis in SPSS 17.0.

of Natural and Cultural Assets of Mali Stapar, 2010). Respondents' responses regarding the possibility of fish farming and development of sport and fishing tourism (Table V) show that the residents of Bezdan, Sombor, Sivac, Turija and Bečej think that there are conditions for the development of fishing tourism on VBK and gave this type of tourism the highest scores (mean value higher than 3.5), whereas the residents of Vrbas, Kula and Bačko Gradište think that this type of tourism does not have prospects (mean value from 1.84 to 2.90). One-way analysis of variance (Table V) and the application of post-hoc Scheffe tests confirmed the difference between respondents at the level of significance $p<0.01(F=10.642, p=0.000)$. The difference can be observed between Vrbas and almost all other settlements, but it is the largest between the residents of Sivac and the residents of Vrbas. Based on the water quality indices, which are very low on the section of the canal between Vrbas and Bačko Gradište, we can see that the negative attitudes of all residents in these settlements are justified. Extremely low values of the WQI on the profiles IV and V, especially in the summer and spring periods of the year (on profile IV - WQI < 30; on profile V - WQI < 70) show that it is almost impossible to develop fishing tourism in this section of the canal. Due to the high level of pollution in certain periods of the year, there are oil spots on the surface of the canal which are the product of wastewater from the surrounding factories. Because of oxygen depletion in the section from Vrbas to Bačko Gradište, there is very often fish kill. The cause of this low concentration of oxygen is a great discharge of easily dissolved organic matter from sugar processing plants, abattoirs and pig farms, as well as untreated sewage water. This situation has a great influence on the decreasing fish stock. All the profiles have a lower WQI in the summer and spring periods compared with fall and winter. One of the factors that can influence water quality is temperature. With an increase in water temperature in the canal, there is an increase in the biological activity and a decrease in the concentration of oxygen (Sánchez et al., 2007). Due to all this, water quality is poorer in the warmer period of the year, having a bad influence on the swimming season and fishing season. Several authors have recorded the same trend for water quality (Couillard and Lefebvre, 1985; Pesce and Wunderlin, 2000; Bordalo et al., 2001; Jonnalagadda and Mhere, 2001; Rudolf et al., 2002; Hernández-Romero et al., 2004). On the other hand, the initial section of VBK, on profiles I and II, i.e. in the vicinity of the settlements Bezdan and Sombor, has water of very good quality. The water quality indices are 
very high (WQI > 80), and water of this quality is appropriate for fishing and swimming (Yunus and Nakagoshi, 2004). This section of the canal includes many csarda restaurants, organized beaches and fishing spots, which greatly contribute to the development of sport and fishing tourism.

Ecotourism is a term generally used to describe travel to a natural place that conserves the environment and improves the well-being of local people (The International Ecotourism Society, 2002). Some representatives of flora and fauna, as well as numerous cultural and historical assets (canal locks, weirs and mills) in this region could be protected, and thus they would represent good potential for the development of ecotourism. Regarding the possibility of ecotourism development (Table V) we can see that the residents of Bezdan, Sivac and Turija think that certain sections of VBK should be put under protection for the preservation of natural and cultural assets, and afterwards ecotourism could be developed in these areas (mean value higher than 4). Residents of Vrbas think that the flora and fauna in this section of the canal is so damaged that there are no conditions for protecting anything (mean value 2.2). By applying one-way analysis of variance (Table V) and the post-hoc Scheffe test, we established that there are differences among respondents from different settlements at the level of significance $p<0.01(F=9.455, p=0.000)$, and that difference is the biggest between the residents of Sivac and Turija and the residents of Vrbas. A basic prerequisite for the development of ecotourism is preserved and not degraded nature. VBK, which represents a hydrographical object of this area, is extremely polluted in certain areas, which is indicated by the data of very poor water quality. On profile IV, near Vrbas, the values of the WQI range from 37 in the fall period to only 25 in the summer period. The quality of water in this area is so poor that a complete absence of flora and fauna was recorded. Polluted water influences the pollution of air and soil. Unpleasant smells and exhaustion fumes pollute air to a great extent, and infiltration and flowing into the ground brings polluted water into the soil. Due to this situation, it is impossible to develop ecotourism at the section of the canal near Kula and Vrbas, which is completely agreed upon by local residents. On the contrary to this situation, the profiles I, II and III near Bezdan, Sombor, Sivac and Crvenka, where the values of the water quality indices show significantly higher values (WQI $=81-86$ in the spring period; $W Q I=90-93$ in the fall period), and which are rich in flora and fauna, local residents recognize as potential resources of ecotourism.

Rural tourism includes a range of activities and complementary services, organized by the rural population in their family homesteads in order to attract tourists and create additional income (Đukić-Dojčinović, 1992). Responses regarding the possibilities of rural tourism development on VBK (Table V) show that residents of Bezdan, Sombor, Sivac and Turija think that there are possibilities for rural tourism development and assess them with high scores (mean value higher than 4), whereas residents of Vrbas think that even this type of tourism development is very hard to achieve (mean value 2.08). As far as the residents of Vrbas are concerned, it is important to mention that up to $6 \%-10 \%$ of the respondents assigned score 1 to this function. A one-way ANOVA (Table V) and the application of the post-hoc Scheffe test confirmed the difference among the respondents from different settlements at the level of significance $p<0.01(F=14.721, p=0.000)$. The biggest difference can be observed between the residents of Vrbas and Bezdan. Although the development of rural tourism is not directly connected to VBK, we can see that the canal itself, i.e. its quality, has a significant influence. It has already been said that the values of the water quality indices on profile IV, near Vrbas, are extremely low (WQI $=25-37$ ), which greatly degrades the canal and its surroundings. Canal pollution, unpleasant smells and dumping grounds in the vicinity have an extremely negative influence on tourism development, which is confirmed by the local residents of Vrbas and its vicinity. In the surrounding areas of these settlements, it is impossible to organize any types of activities in nature. On the initial and final sections of the canal, in the vicinity of the settlements Bezdan, Sombor, Sivac, Turija and Bečej, where the water quality is much better and WQI $>65$ is recorded in all periods of the year, it is possible to conduct activities, such as walks including visits to natural and cultural sites or cycling. 


\section{CONCLUSION}

Tourism as an economic activity brings in increasingly higher incomes, without endangering the environment, and increases the living standard of the population. Tourist destinations and sites along the banks of rivers and canals, with hydro-technical structures of cultural heritage and other complementary services, attract an increasing number of visitors, which boosts economic and demographic development in the area.

Tourism development, especially the development of ecotourism, could have a positive impact on the condition and water quality of VBK. Intensive development of ecotourism and protection of certain sections of the canal could prevent the discharge of harmful wastewater from surrounding industrial facilities that pose the greatest threat to the canal. In addition, intensive training of local residents in the possibilities of rural and ecotourism development would raise awareness about the need to protect the local environment. In this way, rural tourism development would directly impact on reducing pollution and improving the water quality of VBK.

Based on the statistical data analysis, we can see that in the entire course of VBK there are sections (profiles I, II and III) which are clean and completely adequate for tourism development and for using the canal for navigation, recreation and even swimming, and a section (profile IV) which is completely degraded and unusable. The quality of canal water is a basic indicator correlated with positive or negative attitudes of local residents towards the development of different types of tourism in the settlements along VBK. The degree of correlation is high between the quality of canal water and local residents' attitudes. In the sections where the water quality is adequate (profiles I, II and III), local residents have positive attitudes and are ready to support and participate in all the activities aimed at tourism development. On profiles I, II and III, nautical activities, sport-fishing, ecotourism and rural tourism can be developed without any disturbances, whereas the canal profiles IV and V need to be treated in order to create possibilities for the development of certain types of tourism. The pollution of canal water on profiles IV and V is of organic origin and it comes from large industrial facilities. When the main sources of pollution are placed under control, the situation can be alleviated by releasing a larger amount of water from the system of weirs. It is also necessary to treat the vegetation, because several years of poor water flow have created massive strips of reeds along the canals in a lot of sections. This prevents normal water flow in the canal. It should be emphasized that even in the section upstream of Vrbas (profile III), where the canal is considered to be healthy, it is rather eutrophic. The causes of this are wastewaters from upstream communal runoff and agricultural activities. It is also necessary to conduct monitoring along the entire Danube-Tisza-Danube canal system to check water quality, identify the biggest sources of pollution and plan action against them. Then VBK could become a healthy water environment and fulfill the interests of water users in this region. Enjoying nature and fishing are dominant motives that could attract a large number of visitors to the sections of the canal where water quality is adequate, whereas there are no motives for visiting the canal on profile IV. The local population believes that the canal has good conditions for intensive development of ecotourism, rural tourism, and nautical, sports and fishing tourism. The differences in perception of different socio-demographic structures exist, and they are the best reflected in highlighting of ecotourism. The younger male population with a higher level of education emphasizes that this is a promising form of tourism that should be developed in the area of VBK.

Tourists who visit similar destinations in countries with well-developed tourism are interested in cultural heritage and cultural routes in general. VBK should be enriched with offers for multiple-day or one-day stays of tourists and also of residents from neighboring settlements and municipalities. VBK would be adequate for navigation excursions, as well as for nautical and sport events and educational programs. This would provide work for local residents, who could be renting their boats (private ownership) or could be engaged (hired) in the sport clubs to work on training programs, renting vessels, maintaining the club premises, etc. VBK is a very important waterway in Serbia, because it is a part of the Danube-Tisza-Danube (DTD) 
hydro-system. The potential significance of this hydro-system in tourism development of the Republic of Serbia is much wider. It is invaluable and goes beyond local borders. It is a grand hydro-system, due to hundreds of kilometers of navigable canals, numerous weirs and canal locks, some of which represent unique tourism, especially nautical tourism attractions. Its nautical tourism potential comes from a very favorable position in the network of the most important domestic and European inner navigable routes. Navigable canals of the DTD hydrosystem are in immediate contact with the Danube and the Tisza, and from a more global view, they are connected through the Rhine-Main-Danube canal with a network of inner navigable routes of twelve European countries from the North Sea to the Black Sea. In this way, the hydro-system fits into the so-called trans-European Danube route Rotterdam-Sulina.

\section{ACKNOWLEDGMENT}

This paper is part of the project No. 114-451-1861/2011-02 financed by the Provincial Secretariat for Science and Technological Development of the Vojvodina Province, Serbia.

\section{REFERENCES}

Almeida-Santos C. and Buzinde C., 2007. Politics of identity and space. Representational dynamics. J. Travel Res., 45, 322-332.

Andereck K. and Vogt C., 2000. The relations between resident's attitudes toward tourism and tourism development options. J. Travel Res., 39, 27-37.

Andrejev N., 2002. Building and exploitation of old navigable canals in Bačka, Novi Sad (in Serbian).

Andriotis K. and Vaughan R., 2003. Urban residents' attitudes toward tourism development: the case of creta. J. Travel Res., 42, 172-185.

Arvanitoyannis I.S., 2008. Potential and Representatives for Application of Environmental Management System (EMS) to Food Industries, Waste Management for the Food Industries, 3-38.

Banha F. and Anastácio P.M., 2011. Interactions between invasive crayfish and native river shrimp. Knowl. Managt. Aquatic Ecosyst., 401, 17.

Bordalo A.A., Nilsumranchit W. and Chalermwat K., 2001. Water quality and uses of the Bangpakong River (Eastem Thailand). Water Res., 35, 3635-3642.

Brohman J., 1996. New directions for tourism in third world development. Ann. Tourism Res., 23, 48-70.

Brown D.O., 1998. In search of an appropriate form of tourism for Africa: lessons from the past. Tourism Manage., 19, 237-245.

Carlson B., 2002. Public preferences for managing the upper Mississippi River system. Transp. Res. Rec., 1782, 1-10.

Casani S., Rouhany M. and Knøchel S., 2005. A discussion paper on challenges and limitations to water reuse and hygiene in the food industry. Water Res., 39, 1134-1146.

Clements C. J., Schultz H. J. and Lime W. D., 1993. Recreation, tourism, and the local residents: partnership or co-existence? Journal of Park and Recreation Administration, 11, 78-91.

Contreras E.M., Giannuzzi L. and Zaritzky N.E., 2000. Growth kinetics of the filamentous microorganism Sphaerotilus natans in a model system of a food industry wastewater. Water Res., 34, 4455-4463.

Couillard D. and Lefebvre Y., 1985. Analysis of water quality indexes. J. Environ. Manage., 21, 161-179.

Cude C., 2001. Oregon water quality index: a tool for evaluating water quality management effectiveness. J. Am. Water Resour. Assoc., 37, 125-137.

Dalmacija B. and Tumbas-Ivančev I., 2004. Water analysis - quality control, results interpretation, Faculty of Sciences, Department of Chemistry, Novi Sad (in Serbian).

Đekić M. and Šogorov M., 2007. Hydro facilites as Industrial Heritage in Vojvodina, Conference: "Rivers and industrial heritage - Possibilities of reactivation of deserted industrial objects in Serbia: challenges and practice", Belgrade (in Serbian).

Development of a Water Quality Index, 1976. Scottish Development Department, Engineering Division, Edinburgh.

Đukić-Dojčinović, 1992. Rural tourism in Serbia, Turistička štampa, Beograd (in Serbian). 
Đurašković P.N. and Tomić N., 2009. Skadar Lake Water Quality by WQI Method, Conference "Zastita voda 09", Zlatibor, Serbia.

Đurasković P. and Vujović A., 2004. Supplement to the Skadar Lake Water Eutrophication Study, Conference on Water Observation and Information System for Decision Support, Ohrid, Macedonia.

Gillies J.A., Kulshreshtha S.N. and Percy D., 1989. Perception of the value of the south Saskatchewan river. Can. Water Resour. J., 14, 43-53.

Greve W., 1990. Water Quality Including the Ecosystem in Estuarine Water Quality Management, Springer, Berlin, 115-120.

Guo H.C., Chen B., Yu X.L., Huang G.H., Liu L. and Nie X.H., 2006. Assessment of cleaner production options for alcohol industry of China: a study in the Shouguang Alcohol Factory. J. Clean. Prod., 14, 94-103.

Gursoy D. and Rutherford D., 2004. Host attitudes toward tourism. An improved structural model. Ann. Tourism Res., 31, 495-516.

Gursoy D., Jurowski C. and Uysal M., 2002. Resident attitudes: a structural modeling approach. Ann. Tourism Res., 29, 79-105.

Gursoy D., Chi C.G. and Dyer P., 2009. An examination of locals' attitudes. Ann. Tourism Res., 36, 723-726.

Hambright K.D., Parparov A. and Berman T., 2000. Indices of water quality for sustainable management and conservation of an arid region, Lake Kinneret (Sea of Galilee), Israel. Aquat. Conserv., 10, 393-406.

Haralambopoulos N. and Pizam A., 1994. Perceived impacts of tourism: the case of Samos. Ann. Tourism Res., 23, 503-526.

Harzen T., 2000. Mill Restoration Principles, Retrieved from http://www.angelfire.com/journal/ millrestoration/restoration.html (accessed on March 12, 2009).

Hernández-Romero A.H., Tovilla-Hernández C., Malo E.A. and Bello-Mendoza R., 2004. Water quality and presence of pesticides in a tropical coastal wetland in southern Mexico. Mar. Pollut. Bull., 48, $1130-1141$.

Horn C. and Simmons D., 2002. Community adaptation to tourism: comparisons between Rotorua and Kaikoura, New Zealand. Tourism Manage., 23, 133-143.

House M.A. and Newsome D.H., 1989. Water quality indices for the management of surface water quality. Water Sci. Technol., 21, 1137-1148.

Hudson S. and Ritchie J.R.B., 2001. Cross-cultural tourist behavior: An analysis of tourist attitudes towards the environment. J. Travel Tour. Mark., 10, 1-22.

Ishikawa N. and Fukushibe M., 2006. Who expects the municipalities to take initiative in tourism development? Residents' attitudes of Amami Oshima Island in Japan. Tourism Manage., 28, 461-475.

Janaim, S., 1997. Psychological Development, Thaiwattana Publisher, Bangkok.

Jonnalagadda S. B. and Mhere G., 2001. Water quality of the Odzi River in the Eastern highlands of Zimbabwe. Water Res., 35, 2371-2376.

Joy C.M., Balakrishnan K.P. and Joseph A., 1990. Effect of industrial discharges on the ecology of phytoplankton production in the river Periyar (India). Water Res., 24, 787-796.

Kannasombat, S., 1999. The Potential of Traditional Tourist Guides to Become Ecotourism Leaders, Master thesis, Bangkok, Mahidol University.

King, B., Pizam, A. and Milman, A., 1992. Social impacts of tourism: host perceptions. Ann. Tourism Res., 20, 650-665.

Ko D.W. and Stewart W.P., 2002. A structural equation model of residents' attitudes for tourism development. Tourism Manage., 23, 521-530.

Kuvan Y. and Akan P., 2005. Residents' attitudes toward general and forest-related impacts of tourism: the case of Belek, Antalya. Tourism Manage., 26, 691-706.

Lawson R. W., Williams J., Young, T. and Cossens, J., 1998. A comparison of residents' attitudes towards tourism in 10 New Zealand destinations. Tourism Manage., 19, 247-256.

Lee J., Graefe A.R. and Burns R.C., 2004. Service quality, satisfaction, and behavioral intention among forest visitors. J. Travel Tour. Mark., 17, 73-82.

Lepp A., 2007. Residents' attitudes towards tourism in Bigodi village, Uganda. Tourism Manage., 28 , $876-885$.

Likić B., 2002. General overview of the hydro-system Danube-Tisza-Danube, Vode Vojvodine, Novi Sad (in Serbian). 
Lindberg K. and Johnson R.L., 1997. Modeling resident attitudes towards tourism. Ann. Tourism Res., 24, 402-424.

Liou S. M., Lo S.L. and Hu C.Y., 2003. Application of two-stage fuzzy set theory to river quality evaluation in Taiwan. Water Res., 37, 1406-1416.

Maguire I. and Klobučar G., 2011. Size structure, maturity size, growth and condition index of stone crayfish (Austropotamobius torrentium) in North-West Croatia. Knowl. Managt. Aquatic Ecosyst., 401, 12.

Mbaiwa E. J. and Stronza L. A., 2011. Changes in resident attitudes towards tourism development and conservation in the Okavango Delta, Botswana. J. Environ. Manage., 92, 1950-1959.

McGehee N. and Andereck K., 2004. Factors predicting rural residents' support of tourism. J. Travel Res., 43, 131-140.

Melloul A. J. and Collin M., 1998. A proposed index for aquifer waterquality assessment: the case of Israel's Sharon region. J. Environ. Manage., 54, 131-142.

Merrett S., 2007. The price of water: studies in water resource economics and management, IWA Publishing, London.

Mhatre G. N., Chaphekar S. B., Ramani Rao I. V., Patil M. R. and Haldar B. C., 1980. Effect of industrial pollution on the Kalu river ecosystem. Environ. Pollut. A, 23, 67-78.

Miller W. W., Joung H. M. and Mahannah C. N., 1986. Identification of water quality differences in Nevada through index application. J. Environ. Qual., 15, 265-272.

Milošev Ž. 2002. Hidrotechnical works in Banat and Bačka before Danube-Tisza-Danube hydro-system construction, Proceedings: Hydro-system Danube-Tisza-Danube - 25 years later, Vode Vojvodine, Novi Sad (in Serbian).

Milovanov D., 1986. Water cooperatives in Vojvodina 1845-1945, Vode Vojvodine, Novi Sad (in Serbian).

Nagel J.W., 2001. A water quality index for contact recreation. Water Sci. Technol., 43, 285-292.

National Park Service, 2004. Chesapeake and Ohio Canal, The Making of a Park Retrieved from http://www.nps.gov/history/history/online_books/choh/admin_history/history3.htm (accessed on March).

Nives S. G., 1999. Water quality evaluation by index in Dalamatia. Water Res., 33, 3423-3440.

Oregon Water Quality Index Summary Report, Water Years, 1996-2005, Curtis Cude, DEQ Laboratory Division, Water Quality Monitoring Section.

Padtrapornnan, S., 1998. Tourists' Attitudes towards Ecotourism: a Case Study of the National Park in Kanchanaburi Province, Masters thesis, Mahidol University, Bangkok.

Paillisson J.-M., Soudieux A. and Damien J.-P., 2011. Capture efficiency and size selectivity of sampling gears targeting red-swamp crayfish in several freshwater habitats. Knowl. Managt. Aquatic Ecosyst., 401, 06.

Pârvulescu L., Pacioglu O. and Hamchevici C., 2011. The assessment of the habitat and water quality requirements of the stone crayfish (Austropotamobius torrentium) and noble crayfish (Astacus astacus) species in the rivers from the Anina Mountains (SW Romania). Knowl. Managt. Aquatic Ecosyst., 401, 03.

Pec B., 1981. Basic Statistical Methods for Non-mathematicians, Liber, Zagreb (in Croatian).

Pesce S.F. and Wunderlin D. A., 2000. Use of water quality indices to verify the impact of Cordoba City (Argentina) on Suquia River. Water Res., 34, 2915-2926.

Presentation, promotion and activation of natural and cultural assets of Mali Stapar, 2010. Faculty of Sciences, Department of Geography, Tourism and Hotel Management, Novi Sad (in Serbian).

Rajkumar K., Muthukumar M. and Sivakumar R., 2010. Novel approach for the treatment and recycle of wastewater from soya edible oil refinery industry - An economic perspective. Resour. Conserv. Recycl., 54, 752-758.

Republic Hydrometeorological Service of Serbia (RHMS), 2009. Annual Report - Water quality, Republic Hydrometeorological Service of Serbia, Belgrade.

Rudolf A., Ahumada, R. and Pérez, C., 2002. Dissolved oxygen content as an index of water quality in San Vicente Bay, Chile (36 degrees, 450 S). Environ. Monit. Assess., 78, 89-100.

Ryan C. and Cave J., 2005. Structuring destination image: a qualitative approach. J. Travel Res., 44, 143-150.

Sánchez E., Colmenarejo F. M., Vicente J., Rubio A., García G. M., Travieso L. and Borja R., 2007. Use of the water quality index and dissolved oxygen deficit as simple indicators of watersheds pollution. Ecol. Indic., 7, 315-328.

Sangpikul A. and Batra A., 2007. Ecotourism: a perspective from Thai Youths. J. Hosp. Leis. Sport. T. O., 6, 81-85. 
Sayeda M. A., Shawky Z. S., Fayez M., Monib M. and Nabil A. H., 2010. The influence of agro-industrial effluents on River Nile pollution. Journal of Advanced Research, 2, 85-95.

Sheldon P. J. and Abenoja T., 2001. Resident attitudes in a mature destination: the case of Waikiki. Tourism. Manage., 22, 435-443.

Smith D.G., 1989. A new form of water quality index for rivers and streams. Water Sci. Technol., 21, 123-127.

Smith M. and Krannich R., 1998. Tourism dependence and resident attitudes. Ann. Tourism Res., 25, 783-802.

Swamee P.K. and Tyagi A., 2000. Describing water quality with aggregate index. J. Environ. Eng.-ASCE, 126, 451-455.

Teye V., Sirakaya E., and Sönmez S., 2002. Residents' attitudes toward tourism development. Ann. Tourism Res., 29, 668-688.

The International Ecotourism Society, 2002. Ecotourism. (online) Washingon, TIES, available from: http://www.ecotourism.org (accessed 15 May 2002).

Timothy D., 1999. Participatory planning: a view of tourism from Indonesia. Ann. Tourism Res., 26, 371-391.

Vargas-Sánchez A., Plaza-Mejía A. and Porras-Bueno N., 2009. Understanding residents' attitudes toward the development of industrial tourism in a former mining community. J. Travel Res., 47, 373-387.

Vargas-Sánchez A., Porras-Bueno N. and Plaza-Mejía A., 2011. Explaining residents' attitudes to tourism: Is a universal model possible? Ann. Tourism Res., 38, 460-480.

Veljković N., 2000a. Determinig water quality index of the Southern Morava basin by the application of WQI method, Waters Protection 2000, Yugoslav Society for Waters Protection, Belgrade (in Serbian).

Veljković N., 2000b. Indicators of the quality of surface waters from the aspect of integral management of sustainable industrial and urban development in the Southern Morava basin, Master thesis, University of Niš, Faculty of Protection at Workplace, Niš (in Serbian).

Veljković N., 2001. Measuring indicators of sustainable water development for agglomerations in the South Morava basin, 11th Stockholm Water Symposium, Abstract Volume: Building Bridges Through Dialogue, Stockholm.

Veljkovic N., 2003. Indicator of sustainable development of Southern Morava river basin Ecoagglomeration Development Index, Environmental and Public Health Recovery and Protection, UCIS, University of Pittsburgh.

Veljković N. and Jovičić M., 2007. Water quality analysis of the Danube in Serbia by the method of Water Quality Index, Waters Protection 07, Yugoslav Society for Waters Protection, Belgrade (in Serbian).

Vuković N., Vukmirović D. and Radojčić Z., 2002. SPSS practicum, laboratory for statistics, Faculty of Organizational Sciences, University of Belgrade, Belgrade (in Serbian).

Wang X., 2001. Integrating water-quality management and land-use planning in a watershed context. J. Environ. Manage., 61, 25-36.

Wang M., Webber M., Finlayson B. and Barnett J., 2008. Rural industries and water pollution in China. J. Environ. Manage., 86, 648-659.

Weaver D.B., 1998. Ecotourism in the less developed world, CAB International, New York.

Williams J. and Lawson R. 2001. Community issues and resident opinions of tourism. Ann. Tourism Res. , 28, 269-290.

Yoon Y., Gursoy D. and Chen S.J., 2001. Validating a tourism development theory with structural equation modeling. Tourism Manage., 22, 363-372.

Yu H. and Littrell M.A., 2005. Tourists' shopping orientations for handcrafts: What are key influences? J. Travel Tour. Mark., 18, 1-21.

Yunus A.J.M. and Nakagoshi N., 2004. Effects of seasonality on streamflow and water quality of the pinang river in Penang Island, Malaysia. Chin. Geogr. Sci., 14, 153-161.

Zhang J., Inbakaran R. and Jackson M., 2006. Understanding community attitudes towards tourism and host-guest interaction in the urban-rural border region. Tourism Geogr., 88, 182-204. 